This is the accepted version of the following article: He, W. and Silvester, D.S. and Streeter, I. and Aldous, L. and Hardacre, C. and Compton, R. 2009. Measuring the solubility of benzoic acid in room temperature ionic liquids using chronoamperometric techniques. Journal of Physical Organic Chemistry. 22: pp. 6976., which has been published in final form at http://doi.org/10.1002/poc.1428 


\title{
Measuring the Solubility of Benzoic Acid in Room Temperature Ionic Liquids Using Chronoamperometric Techniques
}

\author{
Weisi $\mathrm{He}^{a}$, Debbie S. Silvester ${ }^{a}$, Ian Streeter $^{a}$, Leigh Aldous ${ }^{b}$, \\ Christopher Hardacre ${ }^{b}$ and Richard G. Compton ${ }^{a *}$
}

${ }^{a}$ Department of Chemistry, Physical and Theoretical Chemistry Laboratory, Oxford University, South Parks Road, Oxford OX1 3QZ, United Kingdom

${ }^{b}$ School of Chemistry and Chemical Engineering/QUILL, Queen's University Belfast, Belfast, Northern Ireland BT9 5AG, United Kingdom

To be submitted as an article to: the Journal of Physical Organic Chemistry

${ }^{*}$ Corresponding author

Email: richard.compton@chem.ox.ac.uk

Tel:+44(0) 1865275413

Fax:+44(0) 1865275410 


\section{Abstract}

The electrochemical reduction of benzoic acid (BZA) has been studied at platinum microelectrodes $(10 \mu \mathrm{m}$ and $2 \mu \mathrm{m}$ diameter) in acetonitrile (MeCN) and six room temperature ionic liquids (RTILs): $\left[\mathrm{C}_{2} \mathrm{mim}\right]\left[\mathrm{NTf}_{2}\right],\left[\mathrm{C}_{4} \mathrm{mpyrr}\right]\left[\mathrm{NTf}_{2}\right],\left[\mathrm{C}_{4} \mathrm{mim}\right][\mathrm{OTf}],\left[\mathrm{C}_{4} \mathrm{mim}\right]\left[\mathrm{NO}_{3}\right]$ and $\left[\mathrm{C}_{4} \mathrm{mim}\right]\left[\mathrm{PF}_{6}\right]$ (where $\left[\mathrm{C}_{n} \mathrm{mim}\right]^{+}=1$-alkyl-3-methylimidazolium, $\left[\mathrm{NTf}_{2}\right]^{-}=$bis(trifluoromethylsulfonyl)imide, $\left[\mathrm{C}_{4} \text { mpyrr }\right]^{+}=N$-butyl- $N$-methylpyrrolidinium, $[\mathrm{OTf}]^{-}=$trifluoromethlysulfonate, $\left[\mathrm{NO}_{3}\right]^{-}=$nitrate and $\left[\mathrm{PF}_{6}\right]^{-}=$hexafluorophosphate). Based on the theoretical fitting to experimental chronoamperometric transients in $\left[\mathrm{C}_{4} \mathrm{mpyrr}\right]\left[\mathrm{NTf}_{2}\right]$ and MeCN at several concentrations and on different size electrodes, it is suggested that a fast chemical step preceeds the electron transfer step in a CE mechanism (given below) in both RTILs and MeCN, leading to the appearance of a simple one-electron transfer mechanism.

$$
\begin{gathered}
\mathrm{C}_{6} \mathrm{H}_{5} \mathrm{COOH} \rightleftharpoons \mathrm{C}_{6} \mathrm{H}_{5} \mathrm{COO}^{-}+\mathrm{H}^{+} \\
\mathrm{H}^{+}+e^{-} \rightarrow \frac{1}{2} \mathrm{H}_{2}
\end{gathered}
$$

The six RTIL solvents and acetonitrile were saturated with BZA, and potential-step chronoamperometry revealed diffusion coefficients of $170,4.6,3.2,2.7,1.8,0.26$ and $0.96 \times 10^{-11} \mathrm{~m}^{2} \mathrm{~s}^{-1}$ and solubilities of 131, 75, 78, 74, 220, 2850 and $48 \mathrm{mM}$ in MeCN and the six ionic liquids respectively at $298 \mathrm{~K}$. The high solubility of BZA in $\left[\mathrm{C}_{4} \mathrm{mim}\right]\left[\mathrm{NO}_{3}\right]$ may suggest a strong interaction of the dissolved proton with the nitrate anion. Although there are relatively few literature reports of solubilities of organic solutes in RTILs at present, these results suggest the need for further studies on the solubilities of organic species (particularly acids) in RTILs, because of the contrasting interaction of dissolved species with the RTIL ions. Chronoamperometry is suggested as a convenient methodology for this purpose. 


\section{Keywords}

Benzoic acid, Electrochemical Reduction, Cyclic Voltammetry, Chronoamperometry, Solubility, Diffusion Coefficients, Room Temperature Ionic Liquids, Acetonitrile.

\section{Introduction}

Room temperature ionic liquids (RTILs) are compounds composed entirely of ions and exist in the liquid state at and around $298 \mathrm{~K} \cdot{ }^{1-4}$ RTILs have several unique properties such as lowvolatility, (considered "greener" than volatile organic solvents), ${ }^{1,5,6}$ high thermal stability and can be "tuneable" by simply varying the nature of the cation and anion. ${ }^{7-9}$ RTILs have a wide electrochemical window which allows experiments to be performed that are normally out of the range of traditional solvents e.g. electrodeposition of some metals and semi-conductors. ${ }^{10}$ They have a high intrinsic conductivity (composed entirely of charge carriers), allowing for electrochemical experiments to be performed without added supporting electrolyte, simplifying experimental set-up and minimizing waste. They are currently being used in other applications such as organic and inorganic synthesis, ${ }^{11-13}$ industrial applications,${ }^{6,14}$ catalysis,${ }^{11}$ sensors,${ }^{15}$ solar cells, ${ }^{16}$ fuel cells ${ }^{17}$ and capacitors. ${ }^{18,19}$

The exact nature and relative strength of acidic protons dissolved in room temperature ionic liquid systems is still a topic of investigation. For example, conventional acid-base indicators have been used to physically probe the inherent acidity of ionic liquids, but the observed colour changes are the result of a combination of hydrogen-bonding interactions and the acid-base equilibria. ${ }^{20-22}$ Hardacre et $a l .{ }^{23}$ demonstrate that Friedel-Crafts reactions in ionic liquids based upon $\left[\mathrm{NTf}_{2}\right]^{-}$(bis(trifluoromethylsulfonyl)imide), the acid catalysts $\mathrm{H}[\mathrm{BF} 4]$ and $\mathrm{H}[\mathrm{OTf}]$ (where $\left[\mathrm{BF}_{4}\right]^{-}=$tetrafluoroborate and $[\mathrm{OTf}]^{-}=$trifluoromethlysulfonate) demonstrate significantly lower reaction rates than $\mathrm{H}\left[\mathrm{NTf}_{2}\right]$, despite all three being strong acids in water. 
Del Popolo et al. ${ }^{24}$ simulated the dissolution and solvation of $\mathrm{HCl}$ in the ionic liquid $\left[\mathrm{C}_{1} \mathrm{mim}\right] \mathrm{Cl}$, and observed the rapid formation of the anion $\left[\mathrm{HCl}_{2}\right]^{-}$, rather than dissociation. Several other works have focussed on the behaviour of Bronsted acids in RTILs. ${ }^{25-27}$ Recently, we have reported the oxidation of hydrogen gas $^{28,29}$ and ammonia gas ${ }^{30}$ in RTILs and noted voltammetric behaviour which was mainly dependent on the nature of the RTIL anion. In particular, no reduction waves were observed following the oxidation of $\mathrm{H}_{2}$ in $\left[\mathrm{C}_{6} \mathrm{mim}\right] \mathrm{Cl}$ and $\left[\mathrm{C}_{4} \mathrm{mim}\right]\left[\mathrm{NO}_{3}\right],{ }^{29}$ suggesting the possible formation of $\left[\mathrm{HCl}_{2}\right]^{-}$and $\mathrm{H}\left[\mathrm{NO}_{3}\right]_{2}{ }^{-}$.

In this work, the reduction of benzoic acid (BZA) is reported in acetonitrile (MeCN) and in six commonly-used RTILs: $\left[\mathrm{C}_{2} \mathrm{mim}\right]\left[\mathrm{NTf}_{2}\right],\left[\mathrm{C}_{4} \mathrm{mim}\right]\left[\mathrm{NTf}_{2}\right],\left[\mathrm{C}_{4} \mathrm{mpyrr}\right]\left[\mathrm{NTf}_{2}\right],\left[\mathrm{C}_{4} \mathrm{mim}\right][\mathrm{OTf}]$, $\left[\mathrm{C}_{4} \mathrm{mim}\right]\left[\mathrm{NO}_{3}\right]$ and $\left[\mathrm{C}_{4} \mathrm{mim}\right]\left[\mathrm{PF}_{6}\right]$ (the structures of which are given in Figure 1 ) in order to further try to understand the nature of acid/base behaviour in RTIL media. The electrochemical reduction of weak acids is thought to proceed by the following generic CE mechanism: ${ }^{31-34}$

$$
\begin{gathered}
\mathrm{HA} \underset{k_{-1}}{\stackrel{k_{1}}{\rightleftharpoons}} \mathrm{H}^{+}+\mathrm{A}^{-} \\
\mathrm{H}^{+}+e^{-\stackrel{k_{s}}{\longrightarrow}} \frac{1}{2} \mathrm{H}_{2}
\end{gathered}
$$

Cyclic voltammetry for benzoic acid reduction has previously been reported in water/acidic media, ${ }^{33-35}$ and in the aprotic solvents dimethylformamide (DMF) ${ }^{31}$ and dimethylsulfoxide (DMSO), ${ }^{32}$ appearing to be relatively broad and electrochemically quasi-reversible/ireversible in all cases, and to follow the CE reaction mechanism. The kinetics of the homogeneous step (equation 1) can be studied by observing how the limiting current responds to changes in electrode size and concentration of BZA. ${ }^{36-39}$ In this work, the findings from this type of kinetic analysis is discussed, and the results may have implications both in the understanding of electrode kinetics of CE reactions, and generally in the behaviour of protons in RTILs. 


\section{Experimental}

\subsection{Chemical Reagents}

1-Ethyl-3-methylimidazolium bis(trifluoromethylsulfonyl)imide $\left(\left[\mathrm{C}_{2} \mathrm{mim}\right]\left[\mathrm{NTf}_{2}\right]\right)$, 1-butyl-3-methylimidazolium bis(trifluoromethylsulfonyl)imide $\left(\left[\mathrm{C}_{4} \mathrm{mim}\right]\left[\mathrm{NTf}_{2}\right]\right)$, 1-butyl-1-methylpyrrolidinium bis(trifluoromethylsulfonyl)imide $\left(\left[\mathrm{C}_{4} \mathrm{mpyrr}\right]\left[\mathrm{NTf}_{2}\right]\right)$ and their bromide salt precursors were prepared by standard literature procedures. ${ }^{40,41}$ 1-butyl-3-methylimidazolium tetrafluoroborate $\left(\left[\mathrm{C}_{4} \mathrm{mim}\right]\left[\mathrm{BF}_{4}\right]\right.$ high purity) and 1-butyl-3-methylimidazolium hexafluorophosphate ([ $\left.\mathrm{C}_{4} \mathrm{mim}\right]\left[\mathrm{PF}_{6}\right]$ high purity) were kindly donated by Merck KGaA, and were used as recieved. The synthesis of 1-butyl-3-methylimidazolium nitrate $\left(\left[\mathrm{C}_{4} \mathrm{mim}\right]\left[\mathrm{NO}_{3}\right]\right)$ was adapted from a previously published procedure. ${ }^{42} \mathrm{AgNO}_{3}(5.36 \mathrm{~g}, 0.032 \mathrm{M})$ and $\left[\mathrm{C}_{4} \mathrm{mim}\right] \mathrm{Cl}(5.00 \mathrm{~g}, 0.029 \mathrm{M})$ were dissolved separately in minimum amounts of ultrapure water. The $\left[\mathrm{C}_{4} \mathrm{mim}\right] \mathrm{Cl}$ solution was then slowly added to the stirred $\mathrm{AgNO}_{3}$ solution. After stirring overnight the solution was filtered to remove the $\mathrm{AgCl}$ precipitate, the water removed and the IL dried under high vacuum at 70 ${ }^{\circ} \mathrm{C}$ overnight. The IL was then dissolved in $400 \mathrm{~mL}$ dry methanol, small amounts of activated charcoal and acidic alumina were added as seeds for the remaining $\mathrm{AgCl}$, and the solution left overnight in a freezer. This solution was then filtered and the process repeated. The methanol was removed, and the ionic liquid was dried under high vacuum conditions. Benzoic acid (BDH Limited, $99.5 \%$ ), ferrocene (Aldrich, 98\%), tetrabutylammonium perchlorate (TBAP, Fluka, Puriss electrochemical grade, $>99.99 \%$ ) and acetonitrile (Fischer Scientific, dried and distilled, $>99.99 \%$ ) were used as received without further purification. Nitrogen gas (oxygen free) was purchased from BOC gases, Manchester, UK. 


\subsection{Instrumental}

Electrochemical experiments were performed using a computer controlled $\mu$-Autolab potentiostat (Eco-Chemie, Netherlands). A conventional two-electrode system was employed for all experiments performed in RTILs, with a platinum electrode $(10 \mu \mathrm{m}$ or $2 \mu \mathrm{m}$ diameter $)$ as the working electrode, and a $0.5 \mathrm{~mm}$ diameter silver wire as a quasi-reference electrode. The electrodes were housed in a glass cell "T-cell" designed for investigating microsamples of ionic liquids under a controlled atmosphere. ${ }^{28,43}$ The working electrode was modified with a section of disposable micropipette tip to create a small cavity above the disk into which a drop (20$80 \mu \mathrm{L}$ ) of ionic liquid (containing dissolved BZA) was placed. The RTIL solution was purged under vacuum (Edwards High Vacuum Pump, Model ES 50) for ca. 90 minutes, which served to remove trace atmospheric moisture and gases naturally present in the RTIL. Samples of different concentrations of BZA were systematically diluted in the T-cell with appropriate quantities of blank RTIL solvent. For experiments in MeCN, solutions were housed in a covered glass vial, with a three-electrode arrangement consisting of a $10 \mu \mathrm{m}$ diameter Pt working electrode, a silver wire reference electrode and Pt coil wire counter electrode. The platinum microdisk working electrodes were polished on solf lapping pads (Kemet Ltd., U.K.) using alumina powder (Buehler, IL) of size 1.0 and $0.3 \mu \mathrm{m}$. The electrode diameters were calibrated electrochemically by analyzing the steady-state voltammetry of a $2 \mathrm{mM}$ solution of ferrocene in acetonitrile containing $0.1 \mathrm{M}$ TBAP, using a diffusion coefficient for ferrocene of $2.3 \times 10^{-5} \mathrm{~cm}^{2} \mathrm{~s}^{-1}$ at 298 K. ${ }^{44}$ All experiments were performed inside a thermostated box (previously described by Evans et al. $)^{45}$ which also functioned as a Faraday cage. The temperature was maintained at $298( \pm 1.0) \mathrm{K}$. 


\subsection{Chronoamperometric Experiments}

Chronoamperometric transients were achieved using a sample time of $0.01 \mathrm{~s}(0.001 \mathrm{~s}$ in MeCN). After pre-equilibration for 20 seconds, the potential was stepped from a postion of zero current to a chosen potential after the reductive peak, and the current was measured for $10 \mathrm{~s}(0.5 \mathrm{~s}$ in MeCN). The software package Origin 7.0 (Microcal Software Inc.) was used to fit the experimental data. The equations proposed by Shoup and Szabo $^{46}$ (below) were imported into the non-linear curve fitting function, and the computer was instructed to perform 100 iterations on the data.

$$
\begin{gathered}
I=-4 n F D c r_{\mathrm{d}} f(\tau) \\
f(\tau)=0.7854+0.8863 \tau^{-\frac{1}{2}}+0.2146 \exp \left(-0.7823 \tau^{-\frac{1}{2}}\right) \\
\tau=\frac{4 D t}{r_{\mathrm{d}}{ }^{2}}
\end{gathered}
$$

Here, $n$ is the number of electrons transferred, $F$ is the Faraday constant, $D$ is the diffusion coefficient, $c$ is the initial concentration of parent species, $r_{\mathrm{d}}$ is the radius of the disk electrode, and $t$ is the time. The equations used in this approximation are sufficient to give $D$ and $c$ within an error of $0.6 \%$. The validity of this method in aprotic and RTIL solvents has also been described in a previous publication. ${ }^{47}$

The value for the radius (previously calibrated) was fixed, and a value for the diffusion coefficient and the product of the number of electrons multiplied by concentration was obtained after optimization of the experimental data. It is noted that chronoamperometric transients in MeCN of larger duration than 0.5 seconds showed severe adsorption effects and could not be fitted to the Shoup and Szabo ${ }^{46}$ expression above. 


\section{Results and Discussion}

\subsection{The Reduction of Benzoic Acid in Various RTILs}

The electrochemical reduction of benzoic acid (BZA) has been examined in six different ionic liquids, namely $\left[\mathrm{C}_{2} \mathrm{mim}\right]\left[\mathrm{NTf}_{2}\right],\left[\mathrm{C}_{4} \mathrm{mim}\right]\left[\mathrm{NTf}_{2}\right],\left[\mathrm{C}_{4} \mathrm{mpyrr}\right]\left[\mathrm{NTf}_{2}\right],\left[\mathrm{C}_{4} \mathrm{mim}\right]\left[\mathrm{BF}_{4}\right],\left[\mathrm{C}_{4} \mathrm{mim}\right]\left[\mathrm{NO}_{3}\right]$ and $\left[\mathrm{C}_{4} \mathrm{mim}\right]\left[\mathrm{PF}_{6}\right]$, and acetonitrile. The six ionic liquids were chosen as suitable solvents for electrochemical experiments, since they showed wide, featureless baselines when purged in a vacuum for 90 minutes.

\subsubsection{Cyclic Voltammetry of BZA reduction in RTILs}

Cyclic voltammetry for the reduction of benzoic acid (BZA) on a $10 \mu \mathrm{m}$ diameter Pt electrode has been studied in six RTILs. Figure 2 shows typical voltammetry obtained at 100 and $1000 \mathrm{mV} \mathrm{s}^{-1}$ for the reduction of a saturated solution of BZA in the RTIL $\left[\mathrm{C}_{4} \mathrm{mpyrr}\right]\left[\mathrm{NTf}_{2}\right]$. Steady-state behaviour is observed at $100 \mathrm{mV} \mathrm{s}^{-1}$, and the voltammetry becomes more transient in nature at higher scan rates $\left(1000 \mathrm{mV} \mathrm{s}^{-1}\right)$. It is believed that the reduction peak at $c a$. $1.25 \mathrm{~V}\left(1000 \mathrm{mV} \mathrm{s}^{-1}\right)$ can be assigned to the one-electron CE reduction mechanism, where chemical dissociation of the acid preceeds the electron-transfer step: ${ }^{31-34}$

$$
\begin{gathered}
\mathrm{C}_{6} \mathrm{H}_{5} \mathrm{COOH} \underset{k_{-1}}{\stackrel{k_{1}}{\rightleftharpoons}} \mathrm{C}_{6} \mathrm{H}_{5} \mathrm{COO}^{-}+\mathrm{H}^{+} \\
\mathrm{H}^{+}+e^{-} \stackrel{k_{s}}{\longrightarrow} \frac{1}{2} \mathrm{H}_{2}
\end{gathered}
$$

On the reverse sweep, particularly at higher scan rates, an oxidation peak is observed which suggests either a quasi-reversible process or the oxidation of a product of the reduction. It is believed that this peak is the oxidation of adsorbed hydrogen, consistent with a similar observation observed following the reduction of the ammonium ion in RTILs. ${ }^{30}$ There was no indication of a voltammetric peak for the oxidation of bulk hydrogen at all scan rates studied 
(10 to $4000 \mathrm{mV} \mathrm{s}^{-1}$ ). There is also evidence of a "pre-peak" prior to the main reduction peak, which is suggested to be due to reduction forming adsorbed protons (H•(ads)). This peak, and the oxidation peak were both absent on gold electrodes, consistent with hydrogen being electrochemically inactive on gold. ${ }^{28}$ It should also be noted that the peaks observed are not thought to be due to the reduction of the the BZA ring (which may be possible under some conditions); rather, protons are being reduced, leaving benzoate anions. A detailed mechanistic study in all six RTILs will be reported in a subsequent publication, but has not been included here since it is not the focus of this work. However, the focus will now turn to the measurement of chronoamperometric transients, both to calculate diffusion coefficients and solubilities, and to get an insight on the homogeneous kinetics of the CE reduction mechanism.

\subsubsection{Potential Step Chronoamperometry}

Potential-step chronoamperometry at a microdisk electrode is a commonly used electrochemical technique, and allows the independent calculation of diffusion coefficients and $n c$ values (number of electrons multiplied by concentration) with a known microdisk radius. The approximation commonly used (see equations 3,4 and 5) is described by Shoup and Szabo, ${ }^{46}$ and the validity of this approximation has recently been reported in aprotic and RTIL solvents, ${ }^{47}$ but only applies for a simple $n$ electron-transfer process $i e . \mathrm{A} \pm n e^{-} \rightleftharpoons \mathrm{B}$. In this work, it is believed that if the chemical step (equation 6, dissociation of BZA) is rate limiting, the experimental chronoamperometric transients will not fit the Shoup and Szabo approximation, and the limiting currents will not scale linearly with concentration.

To investigate this, chronoamperometric transients at were obtained for the reduction of saturated solutions of BZA in six ionic liquids. The potential was stepped from a position of zero current (typically $0 \mathrm{~V}$ ) to a potential after the reductive peak, and the current was measured for 10 seconds. In all cases, the theoretical fitting of the Shoup and Szabo expression ${ }^{46}$ 
to experimental transients was excellent $( \pm 0.7 \%)$ on a $10 \mu$ m diameter Pt electrode, implying that the $\mathrm{C}$ step is very fast, giving the response of a simple E step. The diffusion coefficients obtained were of the same order of magnitude $\left(10^{-11} \mathrm{~m}^{2} \mathrm{~s}^{-1}\right)$ as other solid species in RTILs (cf. $5.34 \times 10^{-11} \mathrm{~m}^{2} \mathrm{~s}^{-1}$ for ferrocene in $\left.\left[\mathrm{C}_{2} \operatorname{mim}\right]\left[\mathrm{NTf}_{2}\right]\right),{ }^{48}$ and ca. 1-3 orders of magnitude less than that reported for BZA in water $\left(9.0 \times 10^{-10} \mathrm{~m}^{2} \mathrm{~s}^{-1}\right)^{49}$ and in near critical carbon dioxide $\left(1.3 \times 10^{-8} \mathrm{~m}^{2} \mathrm{~s}^{-1}\right) .{ }^{50}$

The calculated diffusion coefficients obtained from this method are given in Table 1, and appear to decrease with increasing viscosity. The Stokes-Einstein relation ${ }^{51}$ given below (equation 8) predicts a linear relationship between the diffusion coefficients $(D)$ and the inverse of viscosity $\left(\eta^{-1}\right)$ of simple diffusing species. This relationship is commonly followed in conventional molecular solvents, and also for large organic molecules, ${ }^{45}$ ferrocene ${ }^{48}$ and cobaltocenium hexafluorophosphate, ${ }^{48}$ but not for small molecules eg. $\mathrm{O}_{2},{ }^{52} \mathrm{H}_{2},{ }^{29} \mathrm{SO}_{2},{ }^{53} \mathrm{NO}_{2}{ }^{54}$ and $\mathrm{H}_{2} \mathrm{~S}^{55}$ in RTILs.

$$
D=\frac{k T}{6 \eta \pi \alpha}
$$

where $k$ is the Boltzmann constant, $T$ is the temperature and $\alpha$ is the hydrodynamic radius of the diffusing species. A plot of the diffusion coefficient of BZA vs. the inverse of viscosity is shown in Figure 3. An approximate linear relationship is observed (with $\left[\mathrm{C}_{4} \mathrm{mim}\right]\left[\mathrm{NO}_{3}\right]$ an outlier at $\left.0.26 \times 10^{-11} \mathrm{~m}^{2} \mathrm{~s}^{-1}\right)$, suggesting that equation 8 approximately holds for BZA in most RTILs.

Also included in Table 1 are the calculated solubilities of BZA in the six RTILs. The solubilities in the three $\left[\mathrm{NTf}_{2}\right]^{-}$ionic liquids are almost exactly the same, and a slightly lower solubility is observed in $\left[\mathrm{C}_{4} \mathrm{mim}\right]\left[\mathrm{PF}_{6}\right]$. Interestingly, the solubility is higher in $\left[\mathrm{C}_{4} \mathrm{mim}\right]\left[\mathrm{BF}_{4}\right]$, and significantly higher in $\left[\mathrm{C}_{4} \mathrm{mim}\right]\left[\mathrm{NO}_{3}\right]$, suggesting a possible interaction of the dissociated proton with the anion of the RTIL. A strong interaction of protons with the nitrate anion might 
suggest the formation of $\mathrm{H}\left[\mathrm{NO}_{3}\right]$ or $\mathrm{H}\left[\mathrm{NO}_{3}\right]_{2}{ }^{-}$(the hydrogen dinitrate ion). The existance of $\mathrm{H}\left[\mathrm{NO}_{3}\right]_{2}{ }^{-}$is well-known, ${ }^{56-59}$ and its formation in RTILs has been recently suggested. ${ }^{29}$ In general, the solubilities in RTILs are relatively high compared to that reported in water $(28 \mathrm{mM}),{ }^{60}$ but typically similar to than in $\mathrm{MeCN}(850 \mathrm{mM}) \cdot{ }^{60}$

\subsection{Reduction of Different Concentrations of BZA in $\left[\mathrm{C}_{4} \operatorname{mpyrr}\right]\left[\mathrm{NTf}_{2}\right]$}

Since the chronoamperometric transients fit well in all RTILs for high concentrations (saturated solutions) of BZA, the transients were studied at different concentrations of BZA in the RTIL $\left[\mathrm{C}_{4} \mathrm{mpyrr}\right]\left[\mathrm{NTf}_{2}\right]$. It is expected that the steady-state (or chronoamperometric) limiting currents will not scale linearly with concentration for a CE process, except in the case of fast kinetics of the homogeneous step. ${ }^{37,38}$ Figure 4 shows typical experimental (solid lines) and fitted theoretical (dots) chronoamperometric transients for the reduction of BZA in $\left[\mathrm{C}_{4} \mathrm{mpyrr}\right]\left[\mathrm{NTf}_{2}\right]$ at concentrations of $66,55,24$ and $15 \mathrm{mM}$ on a $10 \mu \mathrm{m}$ diameter Pt electrode. Good fitting was observed at all scan rates, and the limiting current was found to increase linearly with concentration of BZA (see Figure 6), suggesting that the homogeneous kinetics of equation 6 are indeed fast in RTILs.

Since it is also known that the kinetics of the homogeneous step can be studied by observing how the limiting current changes as a function of size, ${ }^{36-38}$ chronoamperometric transients were recorded at different concentrations of BZA on a smaller micro-electrode of diameter $2 \mu \mathrm{m}$. Figure 5 shows typical experimental (solid lines) and fitted theoretical (dots) chronoamperometric transients for the reduction of BZA in $\left[\mathrm{C}_{4}\right.$ mpyrr $]\left[\mathrm{NTf}_{2}\right]$ at concentrations of $41,29,17$ and $5 \mathrm{mM}$. Consistent with the results obtained on the $10 \mu \mathrm{m}$ diameter Pt electrode, good fitting was observed at all concentrations. A plot of the limiting current $v s$ concentration of BZA on the $2 \mu \mathrm{m}$ diameter Pt electrode is also included in Figure 6 . The gradient of the line on the $10 \mu \mathrm{m}$ diameter electrode is approximately five times that on the $2 \mu \mathrm{m}$ diameter electrode, 
suggesting that the limiting current is scaling with electrode size, supporting the suggestion of fast kinetics of the homogeneous reaction given in equation 6 , at least in $\left[\mathrm{C}_{4} \mathrm{mpyrr}\right]\left[\mathrm{NTf}_{2}\right]$.

In a previous paper we used numerical simulation to find the limiting current, $I_{\text {lim }}$, for the $\mathrm{CE}$ process at a microdisk. ${ }^{36}$ The results were presented in terms of the value $I_{\lim } / I_{\lim }^{*}$, where $I_{\lim }^{*}$ is the limiting current that would be expected if there was no preceding homogeneous process. For a given value of disc radius, diffusion coefficient and concentration, the value $I_{\lim } / I_{\lim }^{*}$ is dependent only on the equilibrium constant and on the kinetics of the homogeneous process. When the homogeneous process has fast kinetics, or a large equilibrium constant, the value of $I_{\lim } / I_{\lim }^{*}$ is expected to be close to unity, whereas for slow kinetics its value is considerably less. The linear dependence of $I_{\text {lim }}$ on the concentration of BZA suggests we are working in a region where $I_{\lim } / I_{\lim }^{*}$ is close to unity. Figure 7 shows the region where $I_{\lim } / I_{\lim }^{*}>0.95$, assuming a disc radius of $1.1 \mu \mathrm{m}$, a diffusion coefficient of $2.7 \times 10^{-11} \mathrm{~m}^{2} \mathrm{~s}^{-1}$ for all species, and a concentration of $70 \mathrm{mM}$. This figure therefore gives an indication of the possible magnitudes of the rate constant $k_{1}$ for the deprotonation of BZA in $\left[\mathrm{C}_{4} \operatorname{mpyrr}\right]\left[\mathrm{NTf}_{2}\right]$.

\subsection{Voltammetry for BZA Reduction in MeCN}

In order to compare the behaviour in ionic liquids to that obtained in a conventional aprotic solvent, the electrochemistry of BZA reduction was also studied in acetonitrile. Figure 8 shows the reduction of $75 \mathrm{mM} \mathrm{BZA}$ in $\mathrm{MeCN}$ on a $10 \mu \mathrm{m}$ Pt electrode at scan rates of 100 and $1000 \mathrm{mV} \mathrm{s}^{-1}$. The voltammetry observed is steady-state in nature at all scan-rates studied (10$4000 \mathrm{mV} \mathrm{s}^{-1}$ ) and no evidence of a "pre-peak" or oxidation peak (seen in RTILs) was observed. In order to carry out the same kinetic analysis as in RTILs, chronoamperometric transients were recorded for the reduction of BZA at various different concentrations on a $10 \mu \mathrm{m}$ diameter Pt electrode. In all cases, the theoretical fitting of experimental transients was very good, and a diffusion coefficient and concentration was obtained. The average diffusion coefficient obtained 
over the whole range of concentrations studied is given in Table 1, and is approximately two orders of magnitude faster than in RTILs, due to the lower viscosity of MeCN. The solubility could not be easily determined using chronoamperometric measurements due to the formation of crystals at saturated BZA concentrations, so a literature value is given.

Chronoamperometric transients were also recorded at different concentrations on a $2 \mu \mathrm{m}$ diameter Pt electrode in MeCN, since the limiting current will only scale with concentration and electrode size if the homogeneous step is very fast. ${ }^{36-38}$ Figure 9 shows a plot of the chronoamperometric limiting current against the concentration of BZA in MeCN on a $10 \mu \mathrm{m}$ and $2 \mu \mathrm{m}$ diameter Pt electrode. On both electrodes, the limiting current increases linearly with scan rate, and the gradient of the line on the $10 \mu \mathrm{m}$ is approximately five times that on the $2 \mu \mathrm{m}$. This suggests that, similar to the behaviour of benzoic acid in RTILs, the C step given in equation 6 is also very fast in MeCN.

As in section 3.2, we can use the simulated results from our previous paper ${ }^{36}$ to interpret the steady state currents of BZA in MeCN. The linear dependence of $I_{\text {lim }}$ on the concentration of BZA shows that we are working in a region where the value $I_{\lim } / I_{\lim }^{*}$ is near unity. Figure 10 shows the region where $I_{\lim } / I_{\lim }^{*}>0.95$, assuming a disc radius of $1.1 \mu \mathrm{m}$, a diffusion coefficient of $1.7 \times 10^{-9} \mathrm{~m}^{2} \mathrm{~s}^{-1}$ for all species, and a concentration of $100 \mathrm{mM}$. This figure therefore gives an indication of the possible magnitudes of the rate constant for the deprotonation of BZA in $\mathrm{MeCN}$

\section{Conclusions}

Due to the good agreement of theoretical chronoamperometric transients to experimental data, and the linear relationship observed between the limiting current and concentration, the electrochemical reduction of BZA appears to follow a CE mechanism in RTILs and MeCN, with a 
fast homogeneous chemical step preceeding the electrochemical step. As a result, the diffusion coefficients and solubilities of BZA in several RTILs and MeCN have been calculated. A higher

solubility of BZA was observed in $\left[\mathrm{C}_{4} \mathrm{mim}\right]\left[\mathrm{NO}_{3}\right]$, suggesting a strong interaction of the nitrate anion with the acid, otherwise the solubility in the RTILs are similar to those in MeCN.

\section{Acknowledgments}

DSS thanks Schlumberger Cambridge Research and LA thanks the Department of Education and Learning in Northern Ireland and Merck GmBH for funding. 


\section{References}

[1] K. N. Marsh, A. Deev, A. C.-T. Wu, E. Tran, A. Klamt, Korean J. Chem. Eng. 2002, 19, $357-362$.

[2] M. C. Buzzeo, R. G. Evans, R. G. Compton, ChemPhysChem 2004, 5, 1106-1120.

[3] D. S.Silvester, R. G. Compton, Z. Phys. Chem. 2006, 220, 1247-1274.

[4] F. Endres, S. Zein El Abedin, PhysChemChemPhys 2006, 8, 2101-2116.

[5] M. J. Earle, K. R. Seddon, Pure Appl. Chem. 2000, 72, 1391-1398.

[6] J. Dupont, C. Consorti, J. Spencer, J. Braz. Chem. Soc. 2000, 11, 337-344.

[7] J. H. Davis Jr., Chem. Lett. 2004, 33, 1072-1077.

[8] J. H. Davis Jr., Synthesis of task-specific ionic liquids, 2003.

[9] C. Jork, C. Kristen, D. Pieraccini, A. Stark, C. Chiappe, Y. A. Beste, W. J. Arlt, Chem. Thermodyn. 2005, 37, 537-558.

[10] F. Endres, ChemPhysChem 2002, 3, 144-154.

[11] P. Wasserscheid, W. Keim, Angew. Chem. Int. Ed. 2000, 39, 3772-3789.

[12] A. J. Carmichael, M. J. Earle, J. D. Holbrey, P. B. McCormac, K. R. Seddon, Org. Lett. 1999, 1, 997-1000.

[13] I. Meracz, T. Oh, Tetrahedron Letters 2003, 44, 6465-6468.

[14] H. Zhao, Chem. Eng. Commun. 2006, 193, 1660-1677.

[15] M .C. Buzzeo, C. Hardacre, R. G. Compton, Anal. Chem. 2004, 76, 4583-4588. 
[16] N. Papageorgiou, Y. Athanassov, M. Armand, P. Bonhôte, H. Pettersson, A. Azam, M. Grätzel, J. Electrochem. Soc. 1996, 143, 3099-3108.

[17] R. F. de Souza, J. C. Padilha, R. S. Goncalves, J. Dupont, Electrochem. Commun. 2005, $5,728-731$.

[18] M. Ue, M. Takeda, A. Toriumi, A. Kominato, R. Hagiwara, Y. Ito, J. Electrochem. Soc. 2003, 150, A499-A502.

[19] T. Sato, G. Masuda, K. Takagi, K. Electrochim. Acta 2004, 49, 3603-3611.

[20] C. Thomazeau, H. Olivier-Bourbigou, L. Magna, S. Luts, B. Gilbert, J. Am. Chem. Soc 2003, 125, 5264-5265.

[21] D. R. MacFarlane, S. A. Forsyth, ACS Symp. Ser. 2003, 856, 264-276.

[22] D. R. MacFarlane, J. M. Pringle, K. M. Johansson, S. A. Forsyth, M. Forsyth, Chem. Commun. 2006, 1905-1917.

[23] C. Hardacre, S. P. Katdare, D. Milroy, P. Nancarrow, D. W. Rooney, J. M. Thompson, J. Catal. 2004, 227, 44-52.

[24] M. G. Del Popolo, J. Kohanoff, R. M. Lynden-Bell, J. Phys. Chem. B 2006, 110, 87988803.

[25] A. C. Cole, J. L. Jensen, I. Ntai, K. L. T. Tran, K. J. Weaver, D. C. Forbes, Davis Jr., J. H. J. Am. Chem. Soc 2002, 124, 5962-5963.

[26] Y. Du, F. Tian, Synth. Commun. 2005, 35, 2703-2708.

[27] M. A. B. H. Susan, A. Noda, S. Mitsushima, M. Watanabe, Chem. Commun. 2003, 938939. 
[28] D. S. Silvester, L. Aldous, C. Hardacre, R. G. Compton, J. Phys. Chem. B 2007, 111, 5000-5007.

[29] D. S. Silvester, K. R. Ward, L. Aldous, C. Hardacre, R. G. Compton, J. Electroanal. Chem. 2008, in press.

[30] X. Ji, D. S. Silvester, L. Aldous, C. Hardacre, R. G. Compton, J. Phys. Chem. C 2007, 111, 9562-9572.

[31] W. C. Barrette Jr., D. T. Sawyer, Anal. Chem. 1984, 56, 653-657.

[32] S. E. Treimer, D. H. Evans, J. Electroanal. Chem. 1998, 455(1-2), 19-27.

[33] W. Vielstich, D. Jahn, Z. Elektrochem. 1960, 64, 43-44.

[34] W. J. Albery, R. P. Bell, Proc. Chem. Soc. 1963, 169-170.

[35] R. G. Barradas, O. Kutowy, D. W. Shoesmith, Electrochim. Acta. 1974, 19, 49-56.

[36] I. Streeter, R. G. Compton, J. Electroanal. Chem. 2008, in press.

[37] S. Daniele, I. Lavagnini, M. Baldo, F. Magno, Anal. Chem. 1998, 70, 285-294.

[38] S. Daniele, M. Baldo, C. Bragato, M. Abdelsalam, G. Denuault, Anal. Chem. 2002, 74, $3290-3296$.

[39] M. Fleischmann, F. Lasserre, J. Robinson, D. Swan, J. Electroanal. Chem. 1984, 177(1-2), 97-114.

[40] P. Bonhôte, A.-P. Dias, N. Papageorgiou, K. Kalyanasundaram, M. Grätzel, Inorg. Chem. 1996, 35, 1168-1178

[41] D. R. MacFarlane, P. Meakin, J. Sun, N. Amini, M. Forsyth, J. Phys. Chem. B 1999, 103, 4164-4170. 
[42] L. Cammarata, S. G. Kazarian, P. A. Salter, T. Welton, PhysChemChemPhys 2001, 3, 5192-5200.

[43] U. Schröder, J. D. Wadhawan, R. G. Compton, F. Marken, P. A. Z. Suarez, C. S. Consorti, R. F. de Souza, J. Dupont, New J. Chem. 2000, 24, 1009-1015.

[44] M. Sharp, Electrochim. Acta 1983, 28, 301-308.

[45] R. G. Evans, O. V. Klymenko, P. D. Price, S. G. Davies, C. Hardacre, R. G. Compton, ChemPhysChem 2005, 6, 526-533.

[46] D. Shoup, A. Szabo, J. Electroanal. Chem. Interfacial Electrochem. 1982, 140, 237-245.

[47] C. A. Paddon, D. S. Silvester, F. L. Bhatti, T. J. Donohoe, R. G. Compton, Electroanalysis 2007, 19, 11-22.

[48] E. I. Rogers, D. S. Silvester, D. L. Poole, L. Aldous, C. Hardacre, R. G. Compton, J. Phys. Chem. C 2008, 112, 2729-2735.

[49] T. Hotta, S. Nii, T. Yajima, F. Kawaizumi, Chem. Eng. Technol. 2007, 30, 208-213.

[50] O. J. Catchpole, M. B. King, Ind. Eng. Chem. Res. 1994, 33, 1828-1837.

[51] R. G. Compton, C. E. Banks, Understanding Voltammetry, World Scientific, Singapore, 2007.

[52] R. G. Evans, O. V. Klymenko, S. A. Saddoughi, C. Hardacre, R. G. Compton, J. Phys. Chem. B 2004, 108, 7878-7886.

[53] L. E. Barrosse-Antle, D. S. Silvester, L. Aldous, C. Hardacre, R. G. Compton, J. Phys. Chem. B 2008, 112, 3398-3404. 
[54] T. L. Broder, D. S. Silvester, L. Aldous, C. Hardacre, R. G. Compton, J. Phys. Chem. B 2007, 111, 7778-7785.

[55] A. M. O’Mahony, D. S. Silvester, L. Aldous, C. Hardacre, R. G. Compton, J. Phys. Chem. $C$ 2008, in press.

[56] G. Dobinson, R. Mason, D. Russell, Chem. Commun. 1967, 2, 62-63.

[57] B. Faithful, R. Gillard, D. Tuck, R. Ugo, J. Chem. Soc. A 1966, 1185-1188.

[58] A. Sengul, Turk. J. Chem. 2005, 29, 571-578.

[59] L. Siew, B. Sundheim, J. Phys. Chem. 1969, 73, 4135-4141.

[60] M. Chantooni Jr., I. Kolthoff, J. Phys. Chem. 1974, 78, 839-846.

[61] O. O. Okoturo, T. J. VanderNoot, J. Electroanal. Chem. 2004, 568, 167-181.

[62] K. R. Seddon, A. Stark, M.-J. Torres, ACS Symp. Ser. 2002, 819, 34-39.

[63] D. R. Lide, Ed. Handbook of Chemistry and Physics: 76th Edition, CRC Press, 1996. 
Table 1: Chronoamperometric data obtained from theoretical fitting to the Shoup and Szabo ${ }^{46}$ expression for the electrochemical reduction of BZA in ionic liquids and MeCN at $298 \mathrm{~K}$.

\begin{tabular}{lccc}
$\mathrm{RTIL} /$ Solvent & $\eta$ at $293 \mathrm{~K} / \mathrm{cP}$ & $D_{\mathrm{BZA}} / \times 10^{-11} \mathrm{~m}^{2} \mathrm{~s}^{-1}$ & Solubility $/ \mathrm{mM}$ \\
\hline$\left[\mathrm{C}_{2} \mathrm{mim}\right]\left[\mathrm{NTf}_{2}\right]$ & $34^{40}$ & $4.6( \pm 0.3)$ & $75( \pm 2)$ \\
{$\left[\mathrm{C}_{4} \mathrm{mim}\right]\left[\mathrm{NTf}_{2}\right]$} & $52^{40}$ & $3.2( \pm 0.2)$ & $78( \pm 4)$ \\
{$\left[\mathrm{C}_{4} \mathrm{mpyrr}\right]\left[\mathrm{NTf}_{2}\right]$} & $89^{61}$ & $2.7( \pm 0.3)$ & $74( \pm 3)$ \\
{$\left[\mathrm{C}_{4} \mathrm{mim}\right]\left[\mathrm{BF}_{4}\right]$} & $112^{61}$ & $1.8( \pm 0.1)$ & $220( \pm 10)$ \\
{$\left[\mathrm{C}_{4} \mathrm{mim}\right]\left[\mathrm{NO}_{3}\right]$} & $266^{62}$ & $0.26( \pm 0.03)$ & $2850( \pm 200)$ \\
{$\left[\mathrm{C}_{4} \mathrm{mim}\right]\left[\mathrm{PF}_{6}\right]$} & $371^{62}$ & $0.96( \pm 0.05)$ & $48( \pm 3)$ \\
$\mathrm{MeCN}$ & $0.34^{63}$ & $170( \pm 10)$ & $850^{\S 60}$
\end{tabular}

$\S$ The solubility of BZA in MeCN (+0.1 M TBAP) could not be determined using chronoamperometric measurements in this work due to the formation of white crystals at high concentrations of BZA, possibly from a reaction of BZA with TBAP; $D_{\mathrm{BZA}}$ in MeCN was obtained from non-saturated solutions. 


\section{Figure Legends}

1. Structures of all the anions and cations employed in the RTIL solvents in this study.

2. Typical cyclic voltammetry obtained for the reduction of a saturated solution of BZA in the RTIL $\left[\mathrm{C}_{4}\right.$ mpyrr] $\left[\mathrm{NTf}_{2}\right]$ on a $10 \mu \mathrm{m}$ diameter Pt electrode at $298 \mathrm{~K}$, at scan rates of 100 and $1000 \mathrm{mV} \mathrm{s}^{-1}$.

3. Plot of diffusion coefficient, $D,(298 \mathrm{~K})$ of BZA against the inverse of viscosity $(293 \mathrm{~K})$ for the six RTILs studied. $D$ values were obtained from theoretical fitting of chronoamperometric transients to the Shoup and Szabo expression. ${ }^{46}$

4. Experimental (solid lines) and fitted theoretical (dots) chronoamperometric transients for the reduction of BZA in $\left[\mathrm{C}_{4}\right.$ mpyrr $]\left[\mathrm{NTf}_{2}\right]$ on a $10 \mu \mathrm{m}$ diameter Pt electrode at concentrations of (a) 66, (b) 55, (c) 24 and (d) $15 \mathrm{mM}$. The experimental data was theoretically fitted to the Shoup and Szabo ${ }^{46}$ expression following equations 3, 4 and 5.

5. Experimental (solid lines) and fitted theoretical (dots) chronoamperometric transients for the reduction of BZA in $\left[\mathrm{C}_{4}\right.$ mpyrr $]\left[\mathrm{NTf}_{2}\right]$ on a $2 \mu \mathrm{m}$ diameter Pt electrode at concentrations of (a) 41, (b) 29, (c) 17 and (d) $5 \mathrm{mM}$. The experimental data was theoretically fitted to the Shoup and Szabo ${ }^{46}$ expression following equations 3,4 and 5.

6. Plot of the chronoamperometric limiting current vs concentration for the reduction of BZA on a $10 \mu \mathrm{m}$ and $2 \mu \mathrm{m}$ diameter Pt electrode in $\left[\mathrm{C}_{4} \mathrm{mpyrr}\right]\left[\mathrm{NTf}_{2}\right]$ at $298 \mathrm{~K}$.

7. Map showing the values of $K_{\text {eq }}$ and $k_{1}$ that would lead to the experimentally observed behaviour of the steady state currents of BZA in $\left[\mathrm{C}_{4}\right.$ mpyrr $]\left[\mathrm{NTf}_{2}\right] . K_{\text {eq }}$ is defined as $k_{1} / k_{-1}$ 
8. Typical cyclic voltammetry obtained for the reduction of $75 \mathrm{mM}$ BZA in MeCN on a $10 \mu \mathrm{m}$ diameter Pt electrode at $298 \mathrm{~K}$, at scan rates of 100 (dots) and $1000 \mathrm{mV} \mathrm{s}^{-1}$.

9. Plot of the chronoamperometric limiting current vs concentration for the reduction of BZA on a $10 \mu \mathrm{m}$ and $2 \mu \mathrm{m}$ diameter Pt electrode in MeCN at $298 \mathrm{~K}$.

10. Map showing the values of $K_{\text {eq }}$ and $k_{1}$ that would lead to the experimentally observed behaviour of the steady state currents of BZA in MeCN. $K_{\text {eq }}$ is defined as $k_{1} / k_{-1}$. 


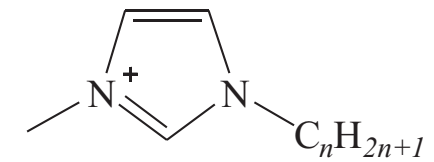

$\left[\mathrm{C}_{n} \operatorname{mim}\right]^{+}$<smiles>O=S(=O)([N-]S(=O)(=O)C(F)(F)F)C(F)(F)F</smiles>

$\left[\mathrm{NTf}_{2}\right]^{-}$

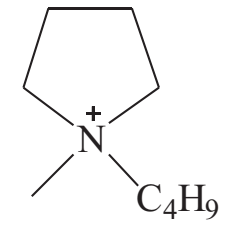

$\left[\mathrm{C}_{4} \text { mpyrr }\right]^{+}$

$\left[\mathrm{PF}_{6}\right]^{-}$

$\left[\mathrm{NO}_{3}\right]^{-}$

Figure 1: Structures of all the anions and cations employed in the RTIL solvents in this study. 


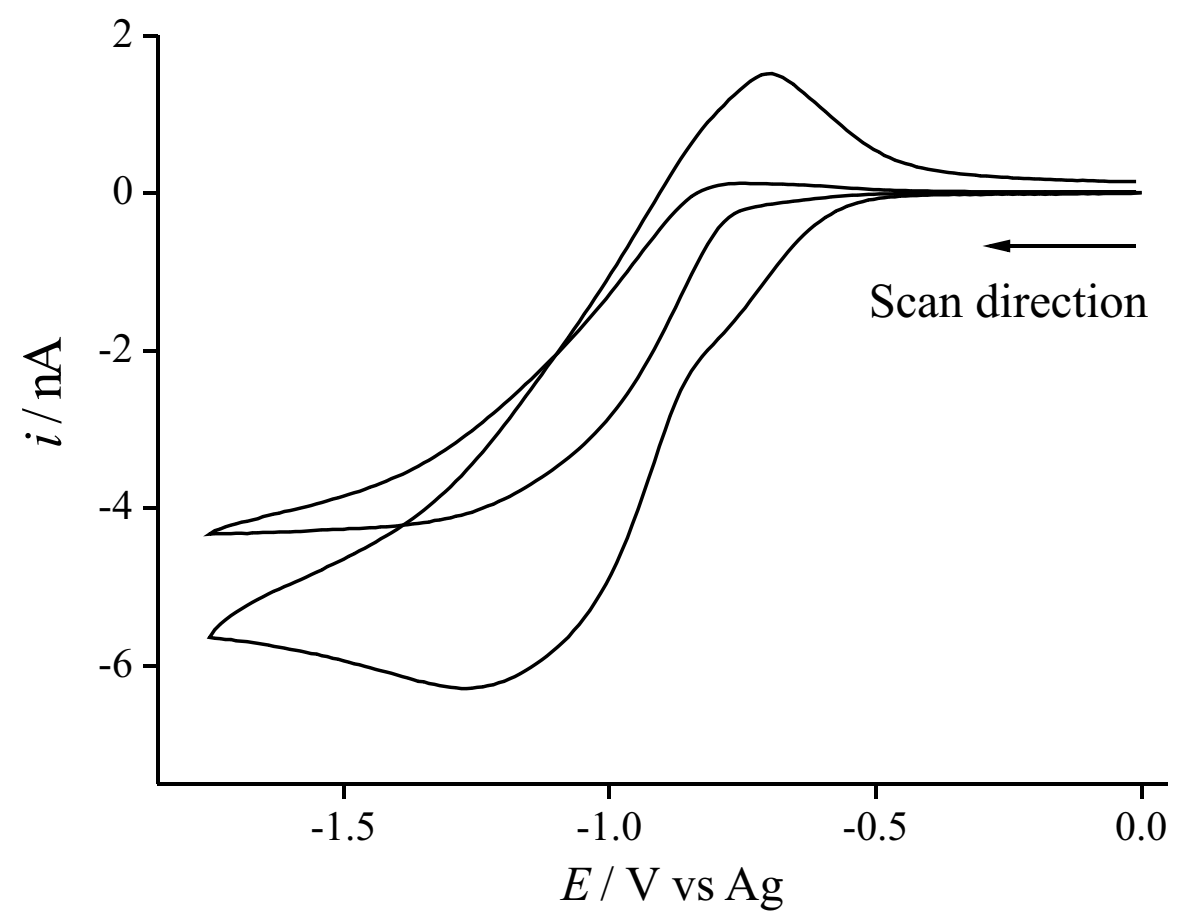

Figure 2: Typical cyclic voltammetry obtained for the reduction of a saturated solution of BZA in the RTIL $\left[\mathrm{C}_{4}\right.$ mpyrr $]\left[\mathrm{NTf}_{2}\right]$ on a $10 \mu \mathrm{m}$ diameter Pt electrode at $298 \mathrm{~K}$, at scan rates of 100 and $1000 \mathrm{mV} \mathrm{s}^{-1}$. 


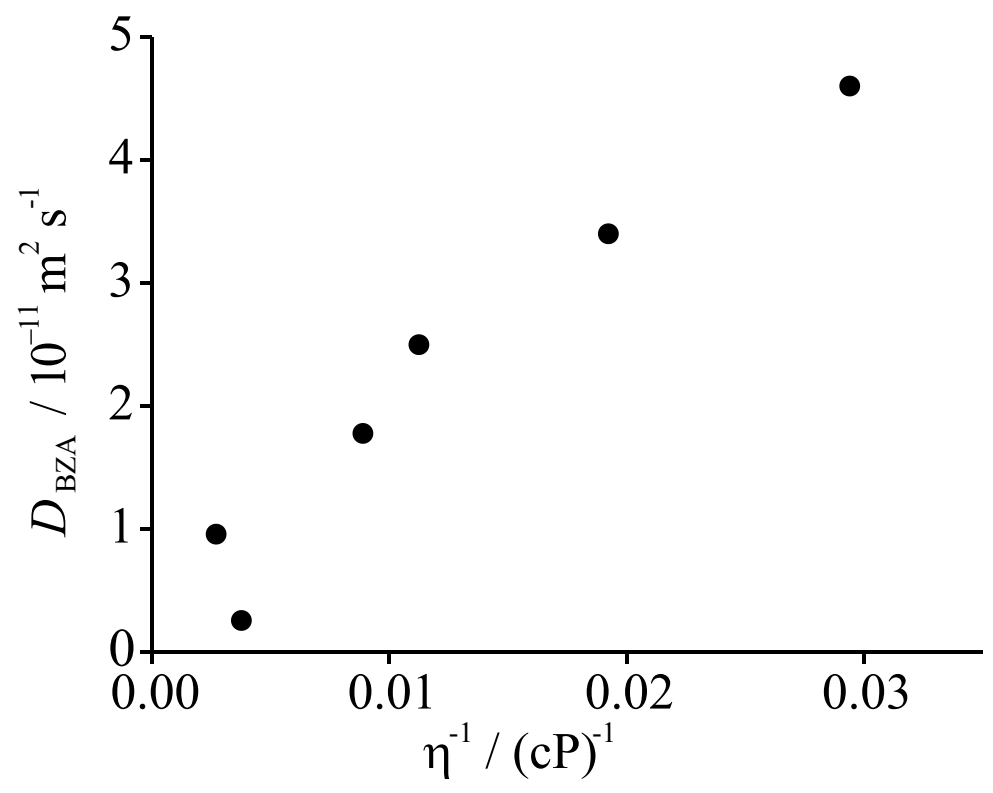

Figure 3: Plot of diffusion coefficient, D, (298 K) of BZA against the inverse of viscosity (293 K) for the six RTILs studied. $D$ values were obtained from theoretical fitting of chronoamperometric transients to the Shoup and Szabo expression. ${ }^{46}$ 

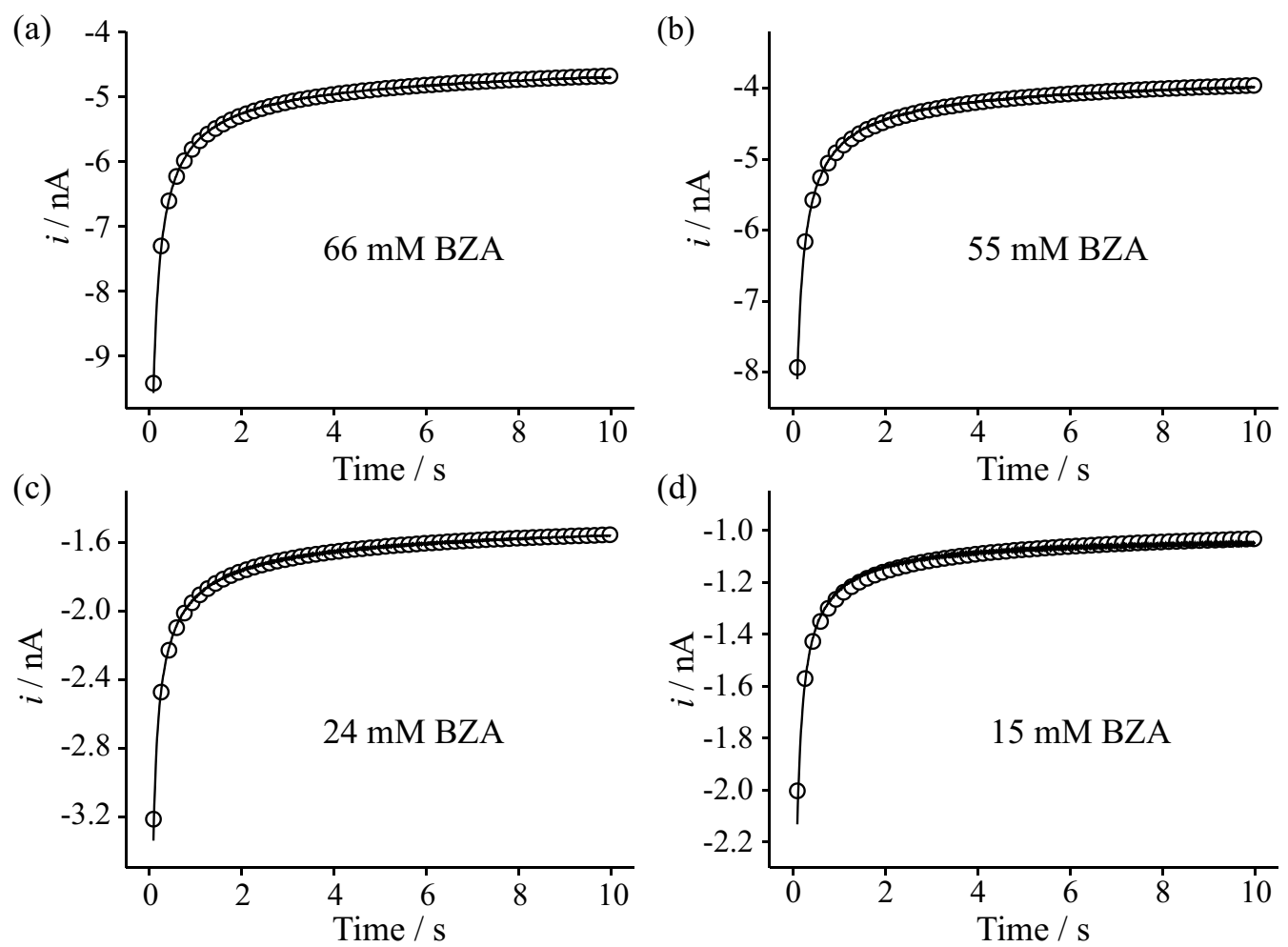

Figure 4: Experimental (solid lines) and fitted theoretical (dots) chronoamperometric transients for the reduction of BZA in $\left[\mathrm{C}_{4}\right.$ mpyrr $]\left[\mathrm{NTf}_{2}\right]$ on a $10 \mu \mathrm{m}$ diameter Pt electrode at concentrations of (a) 66, (b) 55, (c) 24 and (d) $15 \mathrm{mM}$. The experimental data was theoretically fitted to the Shoup and Szabo ${ }^{46}$ expression following equations 3, 4 and 5. 

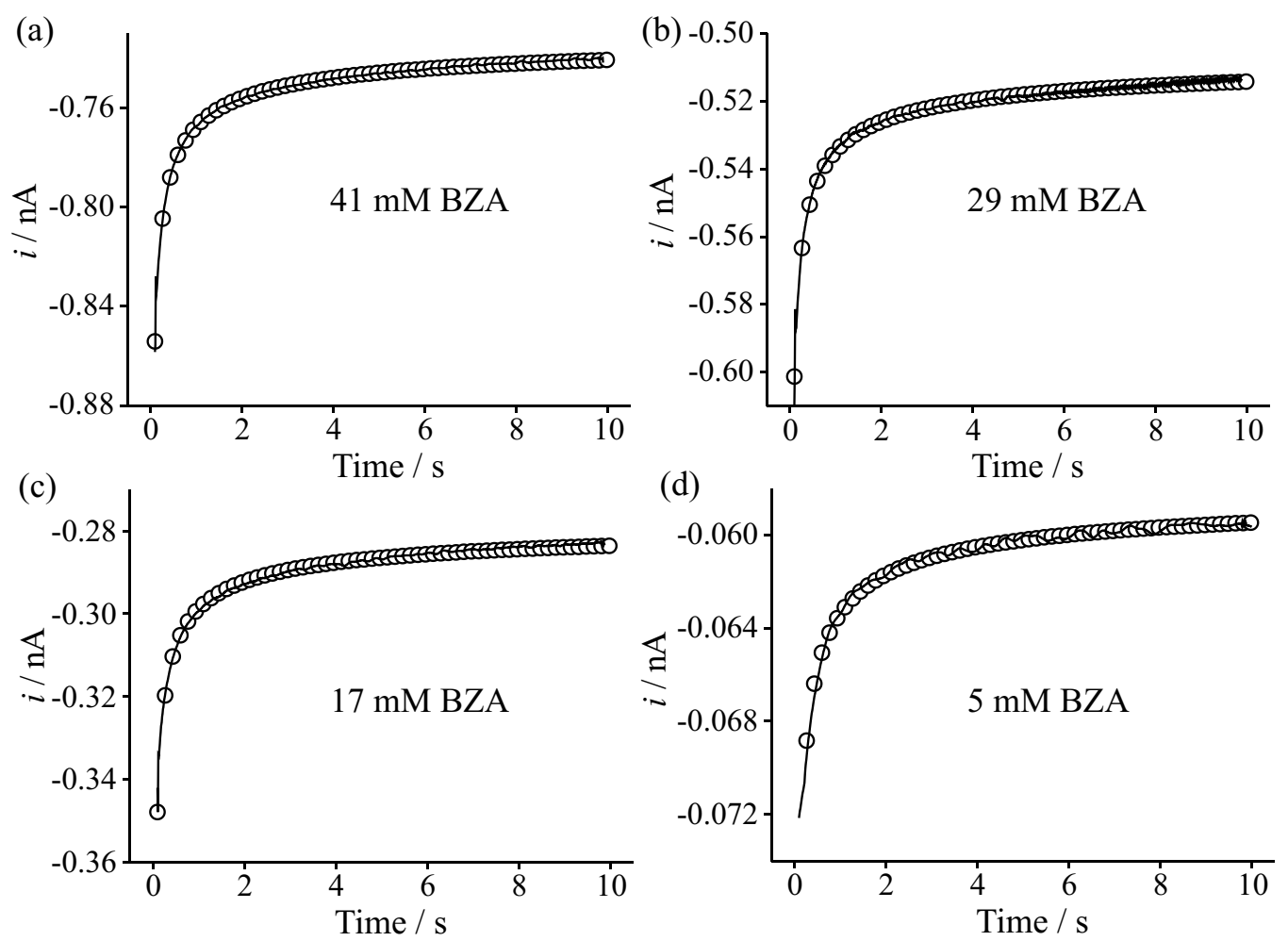

Figure 5: Experimental (solid lines) and fitted theoretical (dots) chronoamperometric transients for the reduction of BZA in $\left[\mathrm{C}_{4} \mathrm{mpyrr}\right]\left[\mathrm{NTf}_{2}\right]$ on a $2 \mu \mathrm{m}$ diameter Pt electrode at concentrations of (a) 41, (b) 29, (c) 17 and (d) $5 \mathrm{mM}$. The experimental data was theoretically fitted to the Shoup and Szabo ${ }^{46}$ expression following equations 3, 4 and 5. 


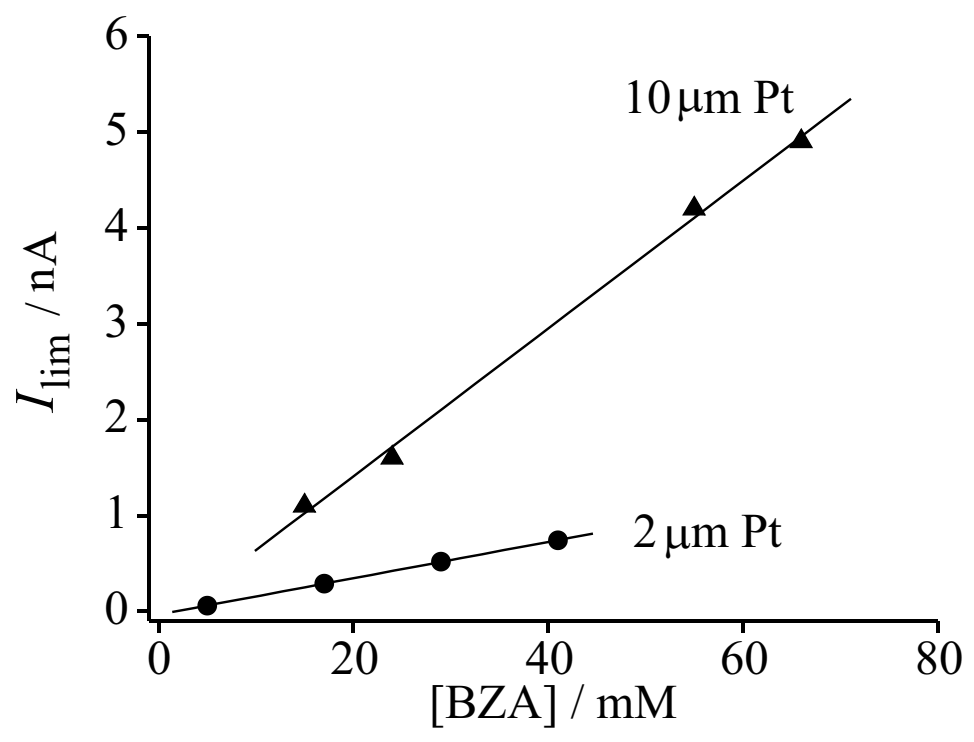

Figure 6: Plot of the chronoamperometric limiting current vs concentration for the reduction of BZA on a $10 \mu \mathrm{m}$ and $2 \mu \mathrm{m}$ diameter Pt electrode in $\left[\mathrm{C}_{4} \mathrm{mpyrr}\right]\left[\mathrm{NTf}_{2}\right]$ at $298 \mathrm{~K}$. 


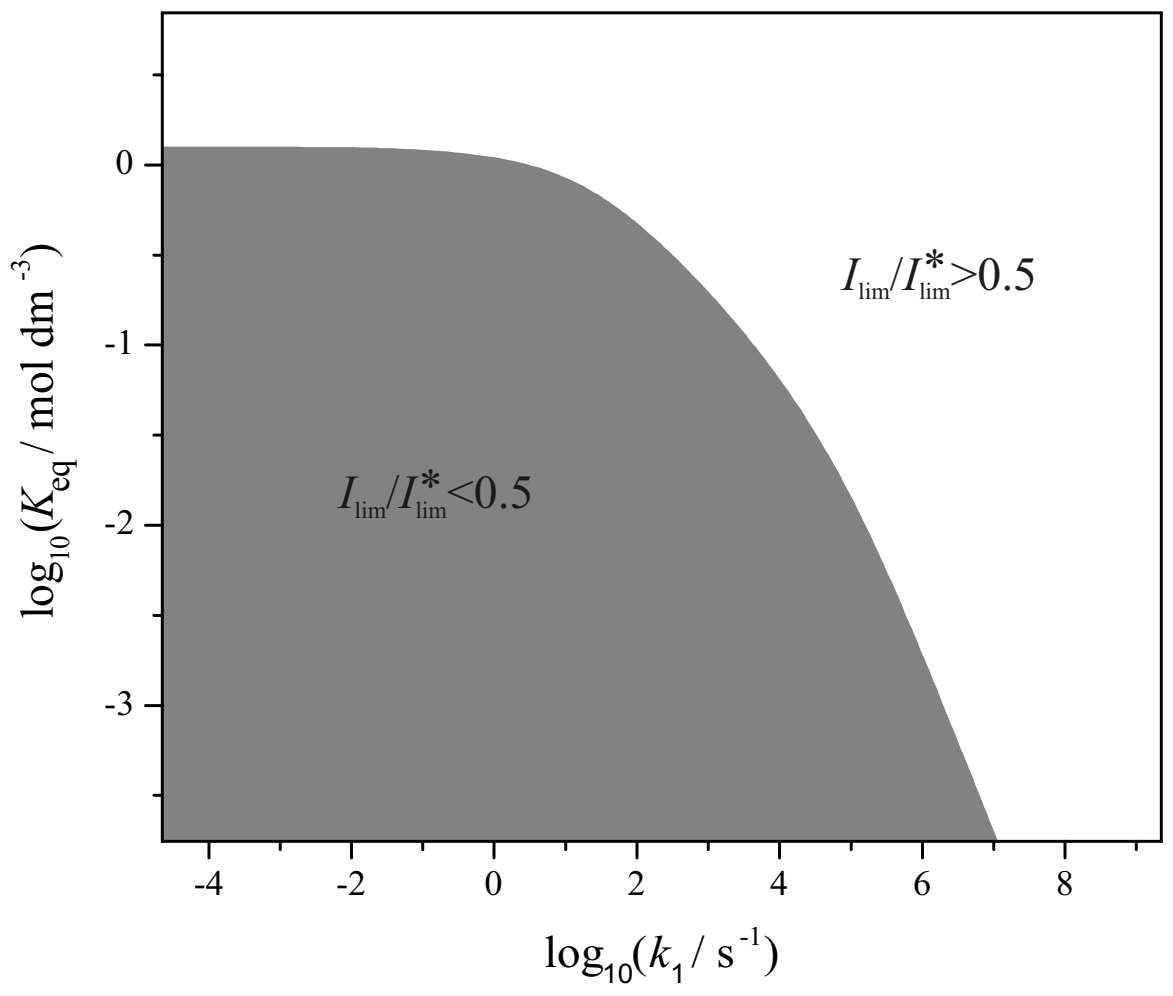

Figure 7: Map showing the values of $K_{\text {eq }}$ and $k_{1}$ that would lead to the experimentally observed behaviour of the steady state currents of BZA in $\left[\mathrm{C}_{4}\right.$ mpyrr $]\left[\mathrm{NTf}_{2}\right] . K_{\text {eq }}$ is defined as $k_{1} / k_{-1}$. 


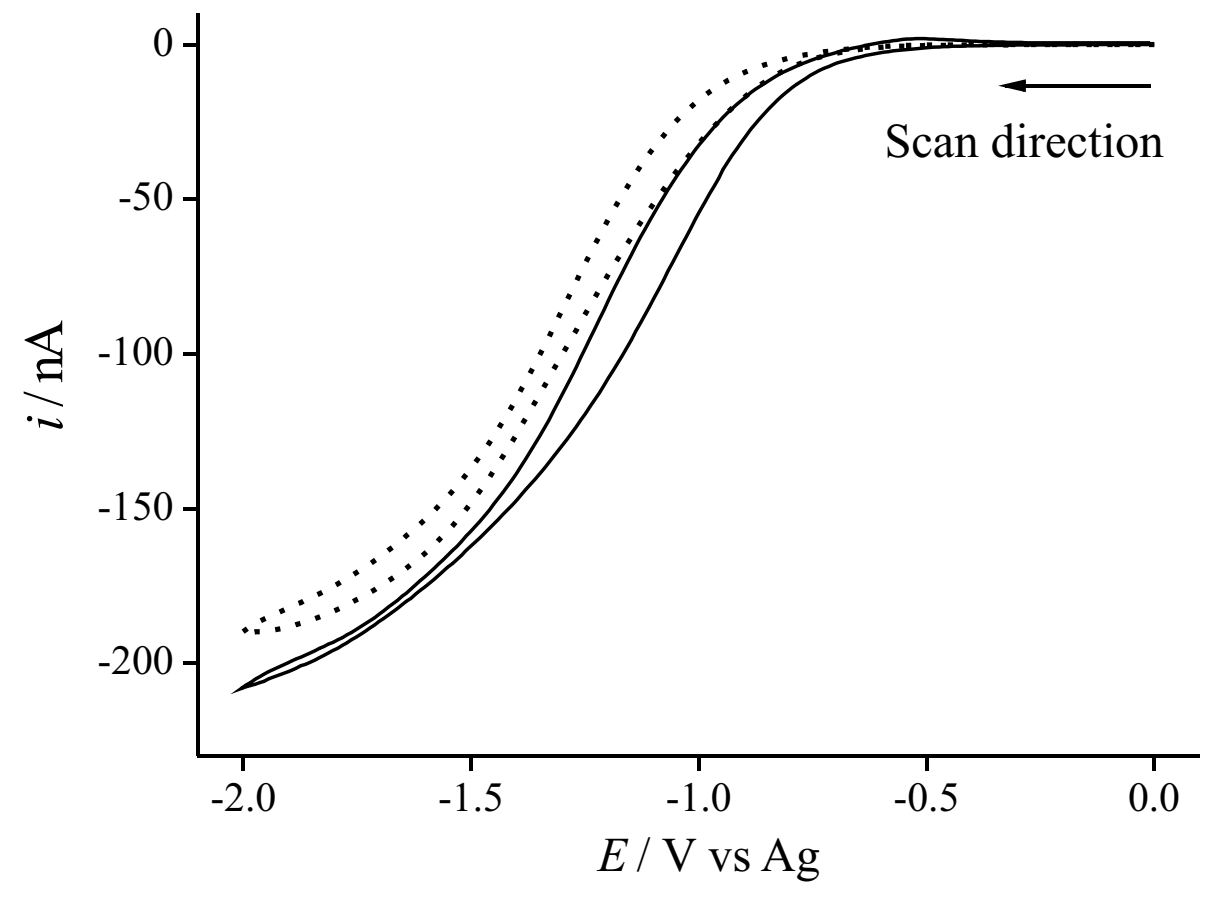

Figure 8: Typical cyclic voltammetry obtained for the reduction of $75 \mathrm{mM}$ BZA in MeCN on a $10 \mu \mathrm{m}$ diameter Pt electrode at $298 \mathrm{~K}$, at scan rates of 100 (dots) and $1000 \mathrm{mV} \mathrm{s}^{-1}$. 


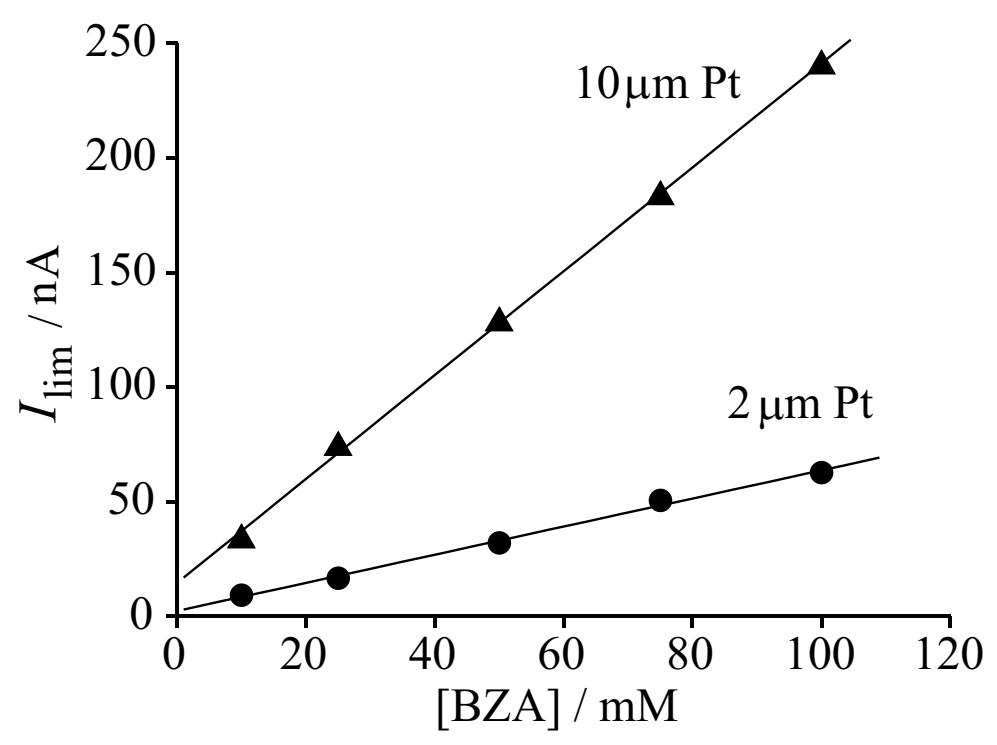

Figure 9: Plot of the chronoamperometric limiting current $v s$ concentration for the reduction of BZA on a $10 \mu \mathrm{m}$ and $2 \mu \mathrm{m}$ diameter Pt electrode in MeCN at $298 \mathrm{~K}$. 


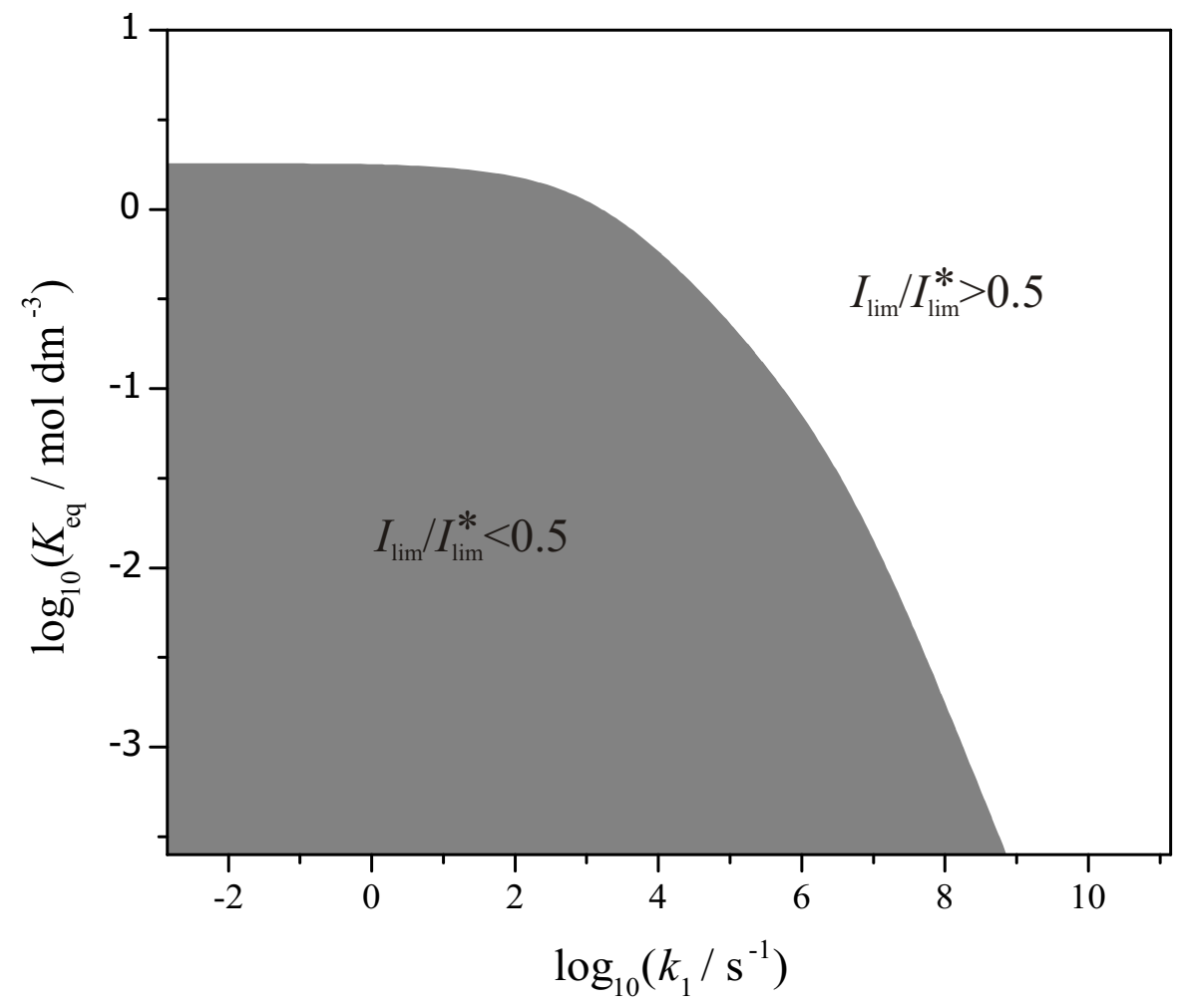

Figure 10: Map showing the values of $K_{\text {eq }}$ and $k_{1}$ that would lead to the experimentally observed behaviour of the steady state currents of BZA in MeCN. $K_{\text {eq }}$ is defined as $k_{1} / k_{-1}$. 